\title{
Benthic-pelagic exchange of microalgae at a tidal flat. 1. Pigment analysis
}

\author{
Cathy H. Lucas ${ }^{1, *}$, John Widdows ${ }^{2}$, Mary D. Brinsley ${ }^{2}$, Peter N. Salkeld ${ }^{2}$, \\ Peter M. J. Herman ${ }^{3}$ \\ ${ }^{1}$ School of Ocean and Earth Science, University of Southampton, Southampton Oceanography Centre, European Way, \\ Southampton SO14 3ZH, United Kingdom \\ ${ }^{2}$ Centre for Coastal and Marine Sciences, Plymouth Marine Laboratory, Prospect Place, The Hoe, Plymouth PL1 3DH, \\ United Kingdom \\ ${ }^{3}$ Netherlands Institute of Ecology (NIOO-CEMO), PO Box 140, 4400 AC Yerseke, The Netherlands
}

\begin{abstract}
Annular flume experiments and high-performance liquid chromatography (HPLC) were used to quantitatively and qualitatively measure benthic-pelagic exchange of microphytobenthos from natural sediments. Clear spatial and temporal differences in microphytobenthos resuspension in response to stepwise increases in current velocity were observed. Resuspension of chlorophyll a (chl a) from sandy sediments containing low levels of microphytobenthos biomass $\left(<11.5 \mathrm{mg} \mathrm{chl} \mathrm{a} \mathrm{m}^{-2}\right)$ occurred gradually and continuously over a range of current velocities from 10 to $40 \mathrm{~cm} \mathrm{~s}^{-1}$. In June,

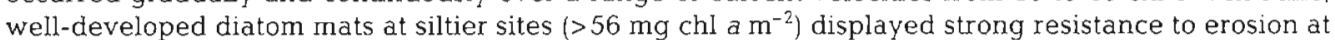
currents $<20$ to $25 \mathrm{~cm} \mathrm{~s}^{-1}$, above which there was a very rapid increase in the amount of chl a in suspension following the stripping of the algal mat from the sediment surface. In September, when the diatom bloom was over, these sediments were less resistant to erosion and resuspension of microalgae occurred at current velocities above 15 to $20 \mathrm{~cm}^{-1}$. Site 1 , situated at the edge of the flat, had a dense algal mat but low sediment stability. Microalgae were readily resuspended because the extracellular polymeric substances (EPS) produced by the migratory diatoms were unable to consolidate during the short emersion period. As a rule more chl a was resuspended from sandy sediments at current velocities 15 and $20 \mathrm{~cm}^{-1}$, but above this current velocity chl a resuspension was greater from silty sediments. Although sandy sites have low biomass in the surface layer, the greater depth of sediment erosion during bedload transport exposes more chl $a$ to the surface. The percentage of sedimentary chl a lost at selected current velocities was estimated, and the implications for carbon supply to the pelagic and benthic systems discussed. Much of the biomass resuspended may be deposited locally, particularly in sandier regions. During the flume experiments it was observed that settling of fine sediment and microalgae was extremely rapid, because it was being biodeposited by suspension-feeding activity, and 'stripped' out of the water column by rapidly sinking suspended particulate matter (SPM). Qualitative changes in suspended material were measured as \% chl a (chl a/phaeopigments $\times 100 \%)$ and accessory pigment content. As current velocity increased the relative proportion of phaeopigments increased, which has important implications for benthic suspension feeders feeding in the benthic boundary layer. The findings from the flume experiments have been compared with in situ measurements of current velocity, SPM and chl a.
\end{abstract}

KEY WORDS: Microphytobenthos - Resuspension - Deposition · Chlorophyll a A Accessory pigments · HPLC · Annular flume

\section{INTRODUCTION}

Understanding the complex interactions involved in the production, transport and transformation of suspended matter in estuaries and coastal seas is of great

·E-mail: catherine.h.lucas@soc.soton.ac.uk importance to biologists and sedimentologists. Microphytobenthos can contribute significantly to total production in estuarine systems (Colijn \& de Jonge 1984, Cahoon \& Cooke 1992, de Jong \& de Jonge 1995, de Jonge \& van Beusekom 1995), and benthic-pelagic exchange of these microalgae can have far-reaching implications. Physical disturbance of diatom and 
cyanobacteria mats leads to increased erodability of the underlying sediment (Delgado et al. 1991) and nutrient flux between pore-water and water column (Sundbäck \& Graneli 1988). The nature of microalgae redistribution is important in determining food quality and quantity available to deposit and suspension feeders (de Jonge \& van Beusekom 1992, Roegner 1998). The significance of this may increase during the late winter-early spring when microphytobenthos blooms develop and phytoplankton biomass remains low (de Jonge \& Colijn 1994).

Microphytobenthos, and particularly benthic diatoms, are closely associated with sediment particles, and are therefore subjected to the same hydrodynamic forces that act on the surrounding sedimentary environment. Cycles of resuspension, deposition and burial are primarily caused by turbulent water currents. These are further influenced by sediment properties/ cohesiveness (Mehta 1988), wave action and storm events (Demers et al. 1987, de Jonge \& van Beusekom 1992, 1995), bioturbation or biostabilisation by the benthos (Jumars \& Nowell 1984, Davis 1993, Grant \& Daborn 1994), and length of time that sediments and extracellular polymeric substances (EPS) produced by

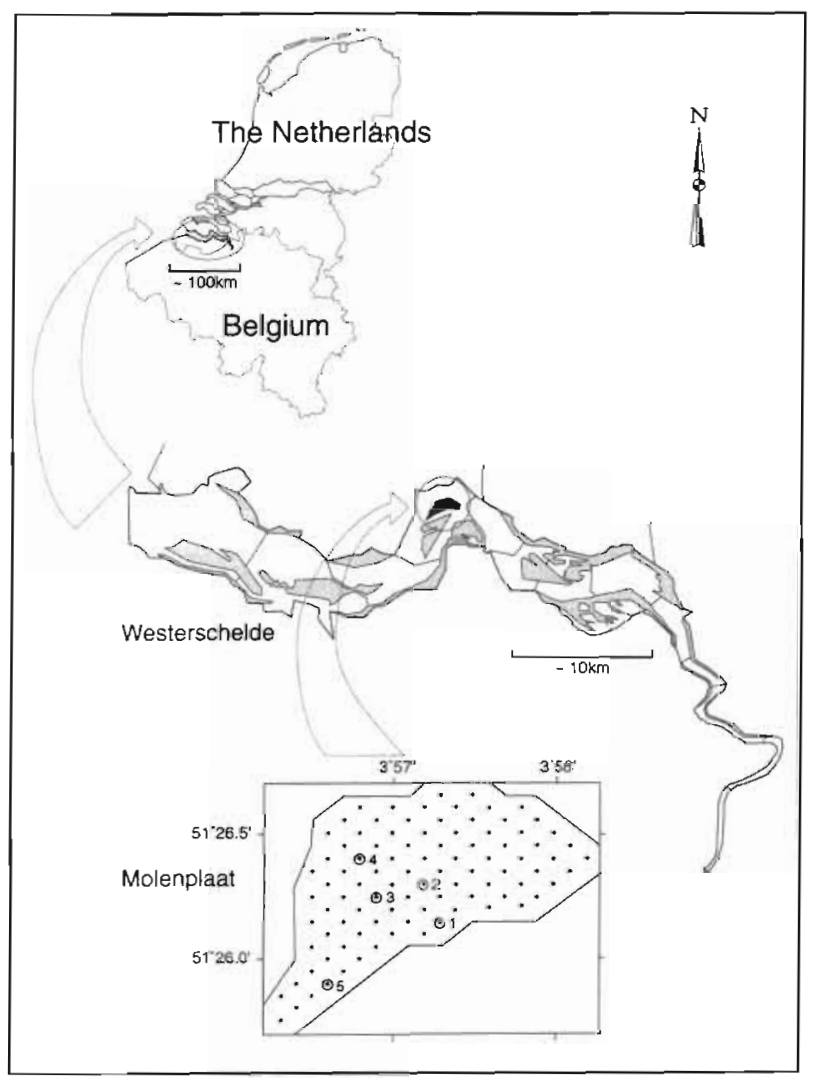

Fig. 1. Map of the Westerschelde estuary, showing the location of the Molenplaat tidal flat and the 5 sampling sites microalgae are exposed to air (Paterson et al. 1990, Yallop et al. 1994). The complex interactions between these mechanisms remain poorly understood.

As part of the EU ELOISE project ECOFLAT, the significance of benthic-pelagic exchange of microalgae to the overall dynamics of the Molenplaat tidal flat (Westerschelde estuary) was examined. The nature and amount of microalgae exchanged to and from natural biotic sediments in response to changes in current velocity in an annular flume has been described and quantified using algal pigment marker and taxonomic methods. These have been compared with in situ measurements of suspended particulate matter (SPM), chlorophyll a (chl a) and current velocity during immersion of the tidal flat. This first paper quantifies the flux of microalgae, together with changes in the quality and type of matter being resuspended at different current velocities, using algal pigment markers. The influence of sediment biochemical and physical properties, and biota such as Macoma balthica and Cerastoderma edule, on sediment erodability and particle flux on the Molenplaat tidal flat has already been described by Widdows et al. (2000).

\section{MATERIALS AND METHODS}

Study area. The Westerschelde estuary (SW Netherlands) is a turbid and eutrophic, well-mixed coastal plain estuary $\sim 100 \mathrm{~km}$ long (Heip 1988). Tidal exchange $\left(\sim 45000 \mathrm{~m}^{3} \mathrm{~s}^{-1}\right)$ is greater than freshwater discharge (50 to $200 \mathrm{~m}^{3} \mathrm{~s}^{-1}$ ), and tidal amplitude in the mid-section is $4 \mathrm{~m}$. Residence times of water masses range between 50 and $70 \mathrm{~d}$ in the upper region, and 10 and $15 \mathrm{~d}$ in the seaward end of the estuary (Soetaert \& Herman 1995b). Although the phytoplankton community is never nitrogen-limited, net pelagic photosynthetic production is relatively low due to the high turbidity in the water column (Kromkamp et al. 1995), and on an estuarine-wide scale, benthic primary production amounts to $60 \%$ of pelagic primary production (Soetaert \& Herman 1995a).

During ECOFLAT, 4 field campaigns were carried out on the Molenplaat tidal flat, situated in the midregion of the estuary: 1 (28 May to 7 June 1996), 2 (27 August to 5 September 1996), 3 (2 to 13 June 1997), and 4 (1 to 12 September 1997). Five sites were chosen (Fig. 1), based on contrasting sedimentological and faunal characteristics (NIOO 1996). The centrally located Site 2 experiences silt accumulation during the summer period, and in June is dominated by benthic suspension feeders such as Cerastoderma edule (5017 $\mathrm{mg}$ ash-free dry weight $[\mathrm{AFDW}] \mathrm{m}^{-2}$ ), and the head-down deposit feeder Heteromastus filiformis (2807 $\mathrm{mg} \mathrm{AFDW} \mathrm{m}^{-2}$ ). Sites 4 
and 5, towards the edge of the flat, are sandy and more dynamic; while Sites 1 and 3 are intermediate in nature. Deposit feeders such as Macoma balthica occur at significant densities at most sites, but in particular at Site 4 (8931 $\mathrm{mg} \mathrm{AFDW} \mathrm{m}^{-2}$ ).

Annular flume experiments. The Plymouth Marine Laboratory (PML) annular flume was used to quantify sediment erodability and microalgae resuspension. The flume has a $64 \mathrm{~cm}$ outer and $44 \mathrm{~cm}$ inner diameter, resulting in a $10 \mathrm{~cm}$ annular channel. Maximum water depth is $38 \mathrm{~cm}$. These dimensions produce a total bed area of $0.17 \mathrm{~m}^{2}$ and maximum volume of $60 \mathrm{l}$. Current velocities ranging from 1 to $50 \mathrm{~cm} \mathrm{~s}^{-1}$ are created by a rotating annulat drive plate without paddles. A detailed description of the design and operational procedures is given in Widdows et al. $(1998 a, b)$.

Sampling and experimental procedures specific to the Molenplaat experiments are described in detail in Widdows et al. (2000). Briefly, flume experiments were carried out on board a Rijkswaterstaat ship moored on the Molenplaat. During the 1st campaign (June 1996) sediment was cut into $10 \mathrm{~cm}$ depth blocks, carefully transported to the ship on polythene-lined trays, and placed into the flume. From the 2nd campaign onwards, sediment was cored to $10 \mathrm{~cm}$ depth using quadrant box cores ( 4 cores forming an annulus) designed to fit the flume precisely. The cores were carefully placed into the flume and the boxes removed, leaving the sediment undisturbed. The measurement of material flux across the sediment-water interface was carried out in 2 phases. During Phase 1 (30 to 40 min duration), clearance and biodeposition rates of particles from the water column is measured at a current velocity of $5 \mathrm{~cm} \mathrm{~s}^{-1}$. Phase 2 (150 min duration) quantifies SPM concentration $\left(\mathrm{mg} \mathrm{l}^{-1}\right)$, mass of sediment eroded ( $\mathrm{g} \mathrm{\textrm {m } ^ { - 2 }}$ ), and sediment erosion rate $\left(\mathrm{mg} \mathrm{m} \mathrm{m}^{-2} \mathrm{~s}^{-1}\right)$ in response to a stepwise increase in current velocity from 10 to $50 \mathrm{~cm} \mathrm{~s}^{-1}\left(5 \mathrm{~cm} \mathrm{~s}^{-1}\right.$ increments, 15 min duration each). SPM concentration is monitored every $15 \mathrm{~s}$ using an optical backscatter sensor (OBS).

Microalgae resuspension in the flume was measured for all 5 sites during the Phase 2 experiments (10 to $\left.50 \mathrm{~cm} \mathrm{~s}^{-1}\right)$. The final measurement of Phase $1\left(5 \mathrm{~cm} \mathrm{~s}^{-1}\right)$ was used as $T_{0}$. Between 50 and $100 \mathrm{ml}$ of water was collected by syringe from $\sim 5 \mathrm{~cm}$ above the sediment surface. Water samples for the measurement of chl a and accessory pigments were filtered immediately through Whatman $\mathrm{GF} / \mathrm{C}$ filters (pore size $1.2 \mu \mathrm{m}$ ), with the addition of 2 to 3 drops of $\mathrm{MgCO}_{3}$. The filters were folded and frozen at $-70^{\circ} \mathrm{C}$ until analysis. Water samples for microalgae identification and enumeration were collected into $50-100 \mathrm{ml}$ brown bottles and preserved with 2 to 3 drops of Lugol's solution. The findings from these samples will be presented elsewhere. Chl a concentration $\left(\mathrm{mg} \mathrm{m}^{-3}\right)$, sediment mass eroded
( $\mathrm{mg} \mathrm{m}^{-2}$ ), and the percentage of benthic microalgal biomass resuspended were quantified, together with qualitative and quantitative changes in phaeopigments and accessory pigments in response to current velocity.

In June 1997, an additional flume experiment was carried out using Site 4 sediment, with the temporal sequence of current velocity simulating the tidal cycle at Site 4 (measured simultaneously with a mini-rig deployment, see later). Sampling was carried out in the same way as described above.

In situ seston dynamics. In May-June 1996 (Sites 2, 3,4 and 5) and August-September 1996 (sites 2, 3 and 4) SPM, chl a and phaeopigments were measured at fixed time and depth intervals for part of the flood-ebb immersion period, lasting 4 to $5 \mathrm{~h}$. Water was collected every 10 to $30 \mathrm{~min}$ using submersed pumps fixed to a post at $30 \mathrm{~cm}$ intervals ( 5 to $215 \mathrm{~cm}$ above the seabed). 500 to $1000 \mathrm{ml}$ of water was analysed for SPM by filtering through pre-dried and pre-weighed Whatman $\mathrm{GF} / \mathrm{C}$ filters, after which they were rinsed with $25 \mathrm{ml}$ of distilled water. Filters were oven-dried overnight at $110^{\circ} \mathrm{C}$, cooled and re-weighed. SPM was calculated from weight difference. 50 to $100 \mathrm{ml}$ of water was sampled for chl a analysis and filtered through Whatman $\mathrm{GF} / \mathrm{C}$ filters, followed by 2 to 3 drops of $\mathrm{MgCO}_{3}$ to prevent acidification of the filter. The filters were folded and frozen until analysis.

In June and September 1997 hydrodynamic and sediment processes were measured at each of the 5 sites using a 'mini-rig' developed at PML. This equipment consisted of a light 4-legged frame (15 mm tubing) which supported an $x-y$ electromagnetic current meter (Valeport $800,5.5 \mathrm{~cm}$ spherical head), an OBS (D \& A Instruments), and a depth pressure sensor (Druck PDCR 940 0-7 Bar absolute). The sensors were mounted $10 \mathrm{~cm}$ above the seabed and were connected to a submersible housing containing a $12 \mathrm{~V}$ power supply and microprocessor controller-logger. Outputs from the instruments were logged every $0.5 \mathrm{~s}$ (with a $24 \times$ over-sampling per channel) for a period of $4 \mathrm{~min}$ 14 s every $10 \mathrm{~min}$ throughout the immersion period. The OBS sensor was calibrated against water samples taken for gravimetric analysis from the flume experiments for each site/sediment type. Water depth, current velocity $\left(\mathrm{cm} \mathrm{s}^{-1}\right)$, current direction ( ${ }^{\circ}$ from $N$ ) and SPM ( $\left.\mathrm{mg} \mathrm{l}^{-1}\right)$ were plotted against time.

Sediment microalgae. Throughout the project, sediment microalgal biomass and composition available for resuspension was identified and quantified (see Lucas \& Holligan 1999). At each site, sediments were collected using $2.54 \mathrm{~cm}$ diameter cut-off syringes, cored to $2 \mathrm{~cm}$ depth, and sectioned on-site. Sections ranged between 2 ( 0 to $6 \mathrm{~mm}$ depth) and $5 \mathrm{~mm}$ (10 to $20 \mathrm{~mm}$ depth). In June 1996, 4 cores were collected randomly 
and the depth sections combined. Thereafter, 4 to 6 cores were collected at fixed points along a linear scale, and the sections analysed individually. Sections were freeze-dried in the dark for 24 to $72 \mathrm{~h}$ (until dry) prior to pigment analysis. Additional samples for microscopic examination were collected and preserved with formaldehyde (ca $2 \%$ final concentration).

Algal pigment analysis. Chl $a$ and its degradation products were measured both fluorometrically and
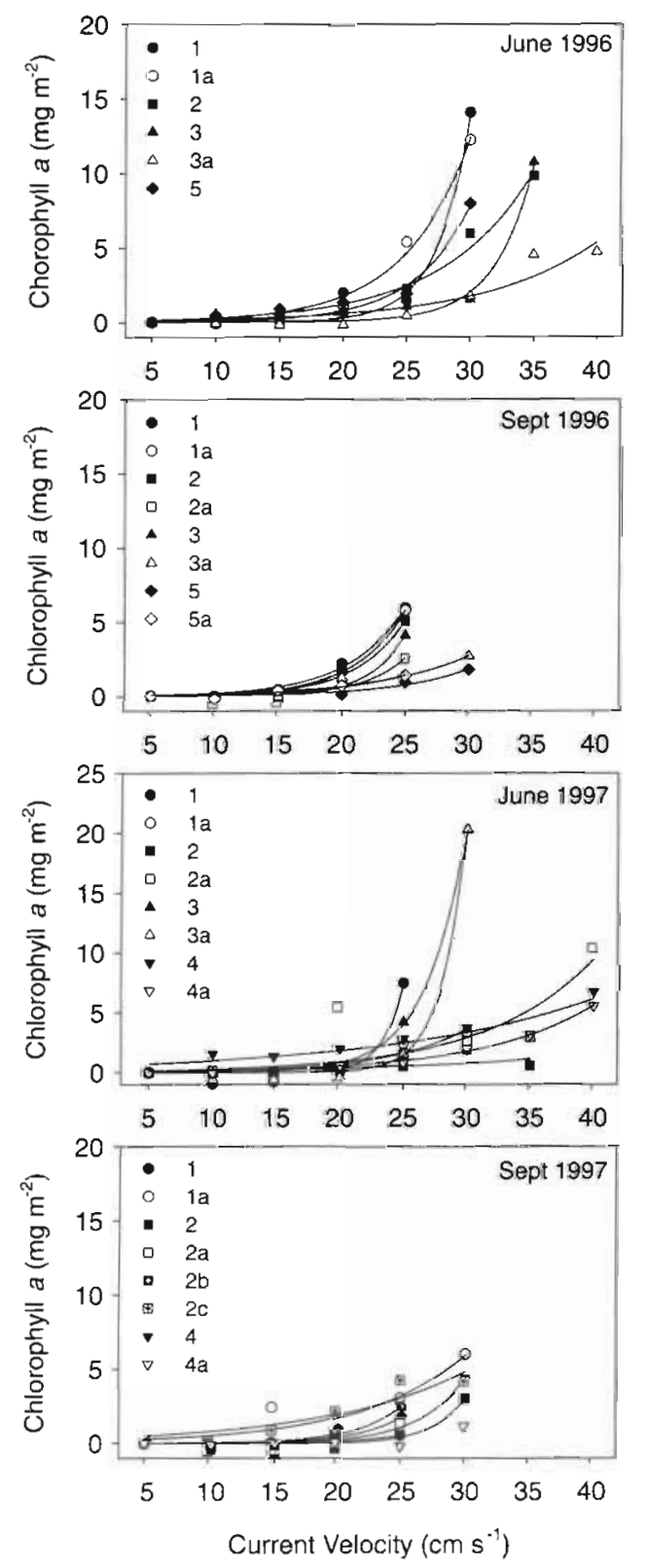

Fig. 2. Flume experiments measuring the mass of chlorophyll a (chl a) resuspended $\left(\mathrm{mg} \mathrm{m}^{-2}\right)$ in response to a stepwise increase in current velocity $\left(\mathrm{cm} \mathrm{s}^{-1}\right)$ from $5 \mathrm{~cm} \mathrm{~s}^{-1}\left(T_{0}\right)$ to $40 \mathrm{~cm}$ $\mathrm{s}^{-1}$. Noniinear regressions $\left(y=a \mathrm{e}^{\mathrm{bx}}\right)$ describing the relationship for each flume experiment are illustrated. (1 and 1a are dupicate experiment.s from Site 1, etc.) by high-performance liquid chromatography (HPLC). Samples for both procedures were extracted in $90 \%$ acetone, ultra-sonicated for $30 \mathrm{~s}$, and centrifuged at $3000 \mathrm{rpm}(2000 \times g)$ for $15 \mathrm{~min}$.

For the fluorometric method, fluorescence of the supernatant was measured using an Aminco fluorometer before and after acidification with 2 drops of $10 \%$ $\mathrm{HCl}$. Absorbance of a chl a standard was measured spectrophotometrically (Cecil 1010) at $665 \mathrm{~nm}$, with a turbidity correction made at $750 \mathrm{~nm}$. Total chl $a$ and phaeopigments were calculated according to the equations of Lorenzen (1967).

The supernatant for HPLC analysis was filtered through a $0.2 \mu \mathrm{m}$ Nyaflo membrane filter. Pigments were determined by reverse-phase HPLC with a $5 \mu \mathrm{m}$ C-18 column (Lucas \& Holligan 1999), a modification of Mantoura \& Llewellyn (1983) described by Barlow et al. (1993). The mobile phase consists of a binary eluant system consisting of eluant A (80\% methanol, $20 \%$ $1 \mathrm{M}$ ammonium acetate), and eluant $\mathrm{B}$ (60\% methanol, $40 \%$ acetone). Dual channel detection was achieved with a UV detector set to $440 \mathrm{~nm}$ for absorbance, and a fluorescence detector set at excitation $410 \mathrm{~nm}$ and emission $670 \mathrm{~nm}$. Pigments were identified by comparing their peaks and retention times with either commercially available standards, or monocultures with well-documented accessory pigment markers. A complete list of pigments and breakdown products of chl a, together with their retention times (Rt) is given in Lucas \& Holligan (1999). The main pigments described in this paper are peridinin (Rt $2.9 \mathrm{~min}$ ), fucoxanthin (4.3), 19'hexanoyloxyfucoxanthin (4.6), zeaxanthin/lutein (6.8), chl $b$ (9.3), and chl a (10.3).

\section{RESULTS}

\section{Flume experiments of chl a resuspension}

The flume experiments demonstrated clear spatial and temporal differences in chl a resuspension in response to stepwise increases in current velocity. The mass of chl a resuspended $\left(\mathrm{mg} \mathrm{m}^{-2}\right)$ versus current velocity (Fig. 2) was best described by the non-linear regression, $y=a e^{b x}$ (values of $p$ were typically $<0.0001$ ).

In general, small positive or negative changes in chl a were observed at current velocities $<15 \mathrm{~cm} \mathrm{~s}^{-1}$. This negative flux, which was particularly noticeable in 1997, is caused by suspension feeder activity and sinking of larger diatom cells. Large increases in the amount of chl a resuspended occurred above 20 to $25 \mathrm{~cm} \mathrm{~s}^{-1}$ in June and above 15 to $20 \mathrm{~cm} \mathrm{~s}^{-1}$ in September (Fig. 2). Resuspension from sandier sediments (Sites 4 and 5) occurred gradually over a wide range of 
Table 1. Mass of chlorophyll a (chl a) and sediment eroded in the flume at current velocities of 15,25 , and $30 \mathrm{~cm} \mathrm{~s}^{-1}$ The critical erosion velocity $\left(U_{\mathrm{cnt}}\right)$ required to increase SPM concentration above a threshold of $100 \mathrm{mg} \mathrm{l^{-1 }}$, and percentage of inmersion time with currents $>U_{\text {crit }}$ are also summarised. (Note: values are means of 2 flume runs for each site $2^{*}=$ cockle-enhanced experiment; negative values $=$ deposition; $\mathrm{nd}=$ not determined)

\begin{tabular}{|c|c|c|c|c|c|c|c|c|c|c|}
\hline \multirow{2}{*}{$\begin{array}{l}\text { Date } \\
\text { Jun } 1996\end{array}$} & \multirow{2}{*}{$\begin{array}{c}\text { Site } \\
1\end{array}$} & $\begin{array}{r}\mathrm{Chl} \\
15 \mathrm{~cm} \mathrm{~s}^{-1}\end{array}$ & $\begin{array}{l}25 \mathrm{~cm} \mathrm{~s}^{-1}\end{array}$ & $\begin{array}{l}\left.30 \mathrm{~cm} \mathrm{~s}^{-2}\right) \\
30 \mathrm{~m}^{-1}\end{array}$ & $\begin{array}{l}\text { Sediment } \\
15 \mathrm{~cm} \mathrm{~s}^{-1}\end{array}$ & $\begin{array}{l}\text { mass erod } \\
25 \mathrm{~cm} \mathrm{~s}^{-1}\end{array}$ & $\begin{array}{l}\text { ed }\left(\mathrm{g} \mathrm{m}^{-2}\right) \\
30 \mathrm{~cm} \mathrm{~s}^{-1}\end{array}$ & $\begin{array}{c}U_{c r i t} \\
\left(\mathrm{~cm} \mathrm{~s}^{-1}\right)\end{array}$ & \multicolumn{2}{|c|}{$\begin{array}{c}\text { Immersion time } \\
\text { above } U_{\text {crit }} \\
\text { Min }\end{array}$} \\
\hline & & 0.34 & 3.41 & 13.16 & 0.3 & 7.0 & 64.8 & 30.4 & $80 / 480$ & 17 \\
\hline & 2 & 0.10 & 2.22 & 5.95 & 0.3 & 7.0 & 29.0 & 31.0 & $50 / 310$ & 16 \\
\hline & 3 & 0.17 & 0.73 & 1.64 & 0.3 & 1.3 & 6.8 & 37.4 & $0 / 270$ & 0 \\
\hline & 5 & 0.88 & 1.87 & 7.97 & 0.3 & 8.6 & 39.5 & 31.3 & $30 / 260$ & 12 \\
\hline Sep 1996 & 1 & 0.36 & 5.84 & nd & 26.6 & 780.9 & 2069.0 & 14.3 & $260 / 530$ & 49 \\
\hline & 2 & -0.22 & 3.78 & nd & 8.9 & 152.2 & 390.6 & 18.0 & $170 / 330$ & 52 \\
\hline & 3 & -0.11 & 2.61 & 2.69 & 1.6 & 116.2 & 457.6 & 21.1 & $100 / 310$ & 32 \\
\hline & 5 & 0.35 & 1.13 & 1.77 & 19.1 & 203.6 & 943.7 & 16.3 & $130 / 300$ & 43 \\
\hline Jun 1997 & 1 & -0.49 & 4.92 & 3.37 & 3.0 & 238.0 & 1150.7 & 20.4 & $160 / 480$ & 33 \\
\hline & 2 & -0.20 & 1.02 & 2.24 & 1.5 & 33.9 & 126.1 & 24.8 & $140 / 310$ & 45 \\
\hline & 3 & -0.38 & 2.84 & 20.26 & 1.7 & 171.5 & 1181.0 & 21.6 & $110 / 270$ & 41 \\
\hline & 4 & 1.33 & 1.80 & 2.83 & 0.7 & 97.4 & 350.2 & 23.0 & $160 / 280$ & 57 \\
\hline Sep 1997 & 1 & 1.23 & 2.39 & 5.98 & 4.9 & 348.2 & 2252.8 & 18.6 & $150 / 530$ & 28 \\
\hline & 2 & -0.10 & 2.06 & 3.80 & 10.8 & 253.5 & 807.8 & 17.2 & $190 / 330$ & 57 \\
\hline & $2 \cdot$ & -0.12 & 2.48 & nd & 16.0 & 330.3 & 954.3 & 13.6 & nd & nd \\
\hline & 4 & 0.06 & 0.18 & 1.17 & 5.4 & 191.0 & 823.2 & 19.3 & $210 / 320$ & 66 \\
\hline
\end{tabular}

current velocities. Well-developed algal mats at the siltier sites in June (Site 2) displayed strong resistance to erosion at currents below 20 to $25 \mathrm{~cm} \mathrm{~s}^{-1}$, after which there was a very rapid increase to high levels (>10 mg $\mathrm{m}^{-2}$ ) following the stripping of the algal mat from the sediment surface. Site 1, located on the edge of the flat, has a dense but unconsolidated algal mat that was easily resuspended at relatively low current velocities during all the carnpaigns. Site 3 displayed great interannual variation between June 1996 and 1997, with the amount of chl a resuspended $12 \times$ greater in 1997 . In general, as current velocities increased, chl a was first resuspended from sandy sediments, and then resuspended from silty sediments.

Table 1 summarises the mass of chl a resuspended at 15,25 and $30 \mathrm{~cm} \mathrm{~s}^{-1}$, together with indices of sediment erodability (mass of sediment eroded, and critical erosion velocity $\left[U_{\text {crit }}\right]$ required to increase SPM concentration above a threshold of $100 \mathrm{mg} \mathrm{l}^{-1}$ ). The relationship between microalgal and sediment resuspension is complex because of differences in the biomass and vertical distribution in the sediment of microphytobenthos over space and time, and differences in the erosion behaviour of sediments. There were no statistically significant relationships between chl a $\left(\mathrm{mg} \mathrm{m}^{-2}\right)$ at a given current velocity and the equivalent mass of sediment eroded, $U_{\text {crit, }}$ or sediment chl a. In June 1996 , when there was very high sediment stability and a well-developed algal mat, $\mathrm{chl}$ a and sediment resuspension were more uncoupled than during other months. In June 1997, and September 1996 and 1997; however, when the sediments were less stable, there was a closer coupling between sediment and microalgal resuspension.

From values of sediment $\mathrm{chl} a$ and the mass of $\mathrm{chl} a$ resuspended, the percentage of sedimentary biomass removed at each current velocity can be estimated (Table 2). Because material from below the surface layer is likely to be removed, both surface (0 to $2 \mathrm{~mm}$ ) and depth-integrated ( 0 to $10 \mathrm{~mm}$ ) biomass have been included to highlight the importance of chl a below the surface layer to the calculation of material fluxes. This is particularly relevant for sandy sediments that have vertically homogenous chl a depth distributions and undergo bedload transport up to several centimetres depth. On average, the percentage of surface biomass resuspended at $25 \mathrm{~cm} \mathrm{~s}^{-1}$ was greater in September $(73.3 \%)$ than June $(27.7 \%)$. For all months and years combined, Site 2 experienced the lowest removal of surface biomass $(26.8 \%)$ at $25 \mathrm{~cm} \mathrm{~s}^{-1}$. The greatest losses were from Site $1(80.5 \%)$, which has high surface biomass, and Site $5(113.0 \%)$, which has low surface biomass. However, differences in the depth of sediment erosion and bedload transport must be taken into consideration.

Although there is good agreement in the overall conclusions between the field and flume experiments, advective fluxes, dispersion and turbulence can make direct extrapolation of flume measurements to the field environment difficult. Nevertheless, in conjunction with the mini-rig current velocity data summarised in Table 3 , the potential significance of the flume resus- 
Table 2. Percent of $\mathrm{chl}$ a from 0 to $2 \mathrm{~mm}$ depth and 0 to $10 \mathrm{~mm}$ depth-integrated sediment resuspended in the flume at current velocities of 15,25 , and $30 \mathrm{~cm} \mathrm{~s}^{-1}$. Values $>100 \%$ at Sites 1 and 5 indicate that more chl a has been resuspended than is available in the surface layer of sediment. (Note: values are means of 2 flume runs for each site; $2^{*}=$ cockle-enhanced experiment; negative values $=$ deposition $;$ nd $=$ not determined)

\begin{tabular}{|c|c|c|c|c|c|c|c|c|c|}
\hline \multirow[t]{2}{*}{ Date } & \multirow[t]{2}{*}{ Site } & \multicolumn{2}{|c|}{$\begin{array}{l}\text { Sediment chl } a \\
\left(\mathrm{mg} \mathrm{m}^{-2}\right)\end{array}$} & \multicolumn{3}{|c|}{$\begin{array}{c}\% \mathrm{chl} \text { a resuspended } \\
\text { from } 0-2 \mathrm{~mm} \text { sediment }\end{array}$} & \multicolumn{3}{|c|}{$\begin{array}{c}\% \text { chl a resuspended } \\
\text { from } 0-10 \mathrm{~mm} \text { sediment }\end{array}$} \\
\hline & & $0-2 \mathrm{mпn}$ & $0-10 \mathrm{~mm}$ & $15 \mathrm{~cm} \mathrm{~s}^{-1}$ & $25 \mathrm{~cm} \mathrm{~s}^{-1}$ & $30 \mathrm{~cm} \mathrm{~s}^{-1}$ & $15 \mathrm{~cm} \mathrm{~s}^{-1}$ & $25 \mathrm{~cm} \mathrm{~s}^{-1}$ & $30 \mathrm{~cm} \mathrm{~s}^{-1}$ \\
\hline \multirow[t]{4}{*}{ Jun 1996} & 1 & 32.67 & 169.56 & 1.05 & 10.43 & 40.27 & 0.20 & 2.01 & 7.76 \\
\hline & 2 & 31.31 & 150.39 & 0.33 & 7.09 & 19.02 & 0.07 & 1.48 & 3.96 \\
\hline & 3 & 15.51 & 146.37 & 1.07 & 4.68 & 10.56 & 0.11 & 0.50 & 1.12 \\
\hline & 5 & 1.25 & 9.01 & 70.58 & 149.97 & 637.96 & 9.79 & 20.80 & 88.50 \\
\hline \multirow[t]{4}{*}{ Sep 1996} & 1 & 2.33 & 23.31 & 15.28 & 250.71 & nd & 1.53 & 25.07 & nd \\
\hline & 2 & 6.22 & 44.80 & -3.61 & 60.72 & nd & -0.50 & 8.43 & nd \\
\hline & 3 & 3.90 & 26.38 & -2.94 & 66.91 & 68.80 & -0.43 & 9.90 & 10.18 \\
\hline & 5 & 1.46 & 7.67 & 24.20 & 77.18 & 121.02 & 4.62 & 14.73 & 23.10 \\
\hline \multirow[t]{4}{*}{ Jun 1997} & 1 & 25.19 & 116.37 & -1.94 & 19.53 & 13.38 & -0.42 & 4.23 & 2.90 \\
\hline & 2 & 56.48 & 249.60 & -0.36 & 1.81 & 3.96 & -0.08 & 0.41 & 0.90 \\
\hline & 3 & 22.93 & 136.53 & -1.65 & 12.40 & 88.32 & -0.28 & 2.08 & 14.84 \\
\hline & 4 & 11.53 & 71.46 & 11.54 & 15.58 & 24.58 & 0.02 & 0.57 & 3.75 \\
\hline \multirow[t]{4}{*}{ Sep 1997} & 1 & 5.82 & 54.89 & 21.08 & 41.13 & 102.76 & 2.24 & 4.36 & 10.90 \\
\hline & 2 & 5.50 & 41.51 & -1.73 & 37.41 & 69.10 & -0.23 & 5.00 & 9.24 \\
\hline & $2^{\circ}$ & 5.50 & 41.51 & -2.12 & 45.01 & nd & -0.28 & 6.02 & nd \\
\hline & 4 & 2.40 & 31.24 & 0.26 & 7.46 & 48.80 & 0.02 & 0.57 & 3.75 \\
\hline
\end{tabular}

Table 3. Field measurements of the maximum current velocity (CV), and time period that each of the CV ranges $<10,10-20$, $20-30,>30 \mathrm{~cm} \mathrm{~s}^{-1}$ lasts during a tidal immersion period on the Molenplaat tidal flat. (nd = not determined)

\begin{tabular}{|c|c|c|c|c|c|c|c|c|}
\hline \multirow{2}{*}{$\begin{array}{l}\text { Date } \\
\text { Jun } 1997\end{array}$} & \multirow{2}{*}{$\begin{array}{c}\text { Site } \\
1\end{array}$} & \multicolumn{2}{|c|}{$\begin{array}{l}\text { Maximum CV } \\
\left(\mathrm{cm} \mathrm{s}^{-1}\right)\end{array}$} & \multirow{2}{*}{$\frac{<10 \mathrm{~cm} \mathrm{~s}^{-1}}{150}$} & \multicolumn{2}{|c|}{$\begin{array}{l}\text { Time period (min) } \\
10-20 \mathrm{~cm} \mathrm{~s}^{-1} \quad 20-30 \mathrm{~cm} \mathrm{~s}^{-1}\end{array}$} & \multirow{2}{*}{$\frac{>30 \mathrm{~cm} \mathrm{~s}^{-1}}{80}$} & \multirow{2}{*}{$\frac{\begin{array}{c}\text { Total } \\
\text { immersion }\end{array}}{480}$} \\
\hline & & 38.4 & Flood & & 150 & 100 & & \\
\hline & 2 & 33.4 & $\mathrm{Ebb}$ & 40 & 60 & 150 & 60 & 310 \\
\hline & 3 & 36.5 & Ebb & 40 & 70 & 140 & 20 & 270 \\
\hline & 4 & 40.5 & $\mathrm{Ebb}$ & 40 & 30 & 130 & 80 & 280 \\
\hline & 5 & 34.8 & Flood & 60 & 80 & 80 & 40 & 260 \\
\hline \multirow[t]{5}{*}{ Sep 1997} & 1 & 40.5 & Flood & 210 & 170 & 100 & 50 & 530 \\
\hline & 2 & 33.5 & Flood & 40 & 140 & 120 & 30 & 330 \\
\hline & 3 & 32.6 & $\mathrm{Ebb}$ & 80 & 100 & 110 & 20 & 310 \\
\hline & 4 & 41.0 & $E b b$ & 40 & 70 & 70 & 140 & 320 \\
\hline & 5 & nd & nd & nd & nd & nd & nd & \\
\hline
\end{tabular}

pension fluxes calculated for 1997 can be implied. Although maximum current velocities ranged between 32.6 and $41.0 \mathrm{~cm} \mathrm{~s}^{-1}$ in 1997, they were greater than $30 \mathrm{~cm} \mathrm{~s}^{-1}$ for only 6 to $20 \%$ (mean $12.7 \%$ ) of the total immersion period at all sites except Site 4 . Thus, the relatively high amounts of chl a that are resuspended at $30 \mathrm{~cm} \mathrm{~s}^{-1}$ or more (Table 2) would only occur for a relatively short period of time within the tidal cycle.

\section{Qualitative changes in resuspended material}

Qualitative differences in microalgal biomass resuspended, expressed as \% chl a (i.e., chl a/phaeopigments $\times 100 \%$ ), changed with increasing current velocity. Data for 1997 are illustrated in Fig. 3. At all 4 sites there was an increase in \% chl a from $5\left(T_{0}\right)$ to $10 \mathrm{~cm} \mathrm{~s}^{-1}$ (15 $\mathrm{cm} \mathrm{s}^{-1}$ at Site 1$)$ so that values were typically 40 to $50 \%$. Above $15 \mathrm{~cm} \mathrm{~s}^{-1}, \% \mathrm{chl}$ a decreased with increasing current velocity to $<20 \%$ by $2.5 \mathrm{~cm} \mathrm{~s}^{-1}$, after which there appeared to be a levelling off.

Comparison of accessory pigment markers from sediments and resuspended material from 2 contrasting sites (Sites 2 and 4) with different physical and microphytobenthos characteristics are illustrated in Figs. 4 (June 1997) \& 5 (September 1997). In June and September the microphytobenthos community at both sites was dominated by benthic diatoms (fucoxanthin:chl a $>0.6$ ). Site 2 sediments had high pigment diversity because of the additional presence of material from 

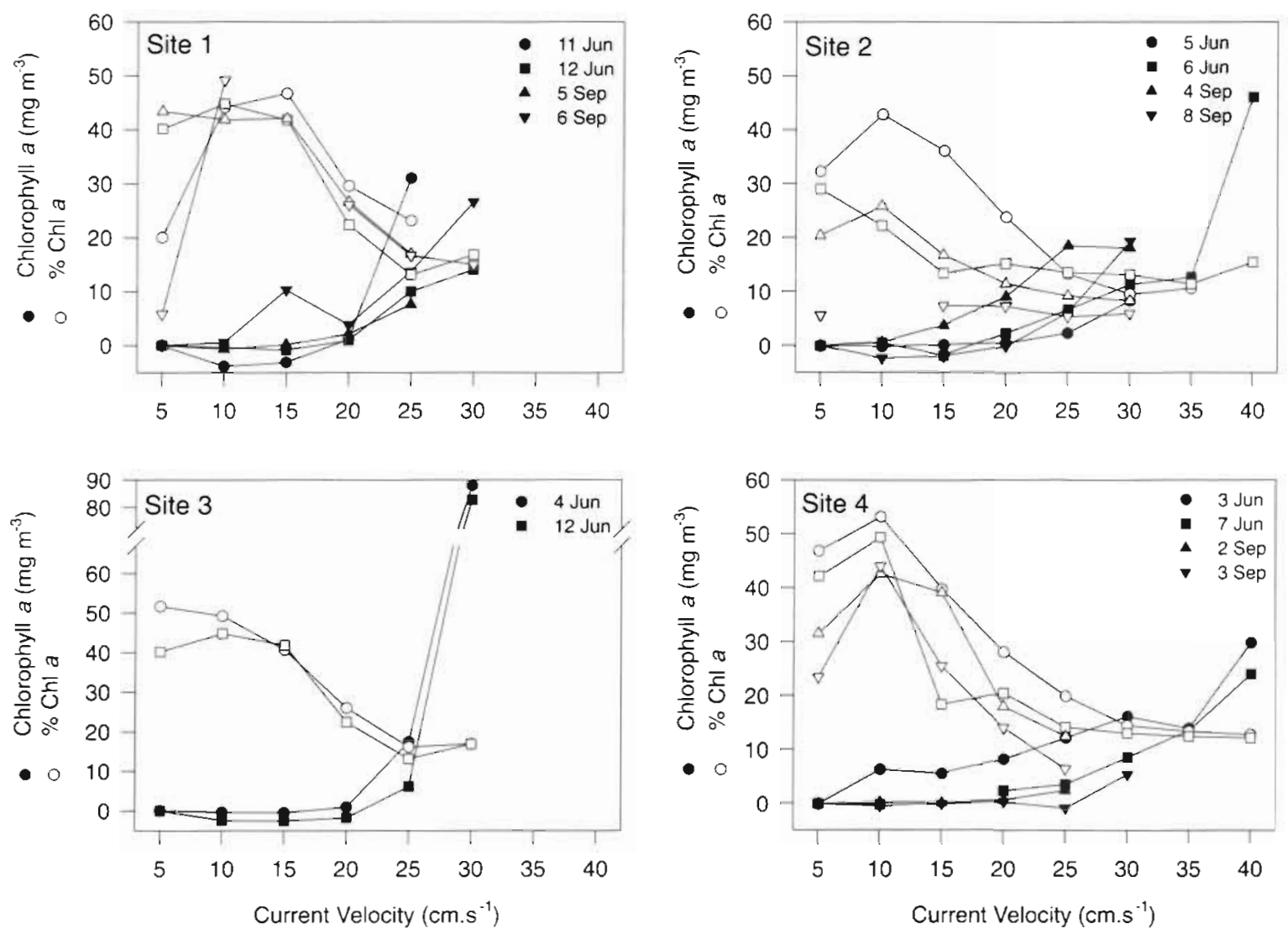

Fig. 3. Flume experiments measuring changes in $\mathrm{chl} \mathrm{a}\left(\mathrm{mg} \mathrm{m}^{-3}\right)$ and $\% \mathrm{chl} a$ (of phaeopigments) in response to changes in current velocity at Sites 1, 2, 3 and 4 in 1997

water column sources (e.g., 19'hexanoyloxyfucoxanthin and peridinin). Although chl a decreased between June and September ( 56.5 to $5.5 \mathrm{mg} \mathrm{m}^{-2}$ ), the relative amount of accessory pigments increased in September, caused by deposition and accumulation of algal and detrital material throughout the stable sediment. The unstable sediments at Site 4 were characterised by low biomass and pigment diversity. Non-diatomaceous pigments such as zeaxanthin/lutein, peridinin, and 19 'hexanoyloxyfucoxanthin were patchily distributed in the vertical below the surface.

In general, changes in the pigment characteristics of resuspended material reflected differences in the underlying sediment. Although the overlying water at $T_{0}$ was dominated by diatoms (fucoxanthin:chl a $\sim 0.7$ ), ratios increased with increasing current velocity, indicating that benthic diatoms were being resuspended from the sediment, enhancing the water column population (see $5 \mathrm{~cm} \mathrm{~s}^{-1}$ for water column characteristics).

At Site 2 the seasonal increase in the relative amount of sedimentary fucoxanthin was reflected in the suspended material. Changes in fucoxanthin:chl a with increasing current velocity were greater in September as the sediment was less stable and eroded to greater depths. In September the onset of resuspension at $15 \mathrm{~cm} \mathrm{~s}^{-1}$, following deposition at $10 \mathrm{~cm} \mathrm{~s}^{-1}$, is clearly demonstrated by the sudden appearance of relatively high amounts of peridinin, zeaxanthin/ lutein and 19'hexanoyloxyfucoxanthin. These accessory pigments were present in the resuspended material in June, although changes with increasing current velocity were not large and did not change with increasing chl a concentration. These data suggest that the surface layer only was being eroded.

At Site 4, resuspension of diatoms occurred continuously and gradually from 10 to $40 \mathrm{~cm} \mathrm{~s}^{-1}$ in June. Other accessory pigments only appeared above $15 \mathrm{~cm} \mathrm{~s}^{-1}$. These pigments were not readily apparent in the upper $2 \mathrm{~cm}$ of sediment, but it is likely that they are found in the deeper layers, and therefore reflect the greater depth of sediment erosion occurring at Site 4. In September, when there was very low sediment biomass available for resuspension, changes in $\mathrm{chl} a$ and fucoxanthin:chl a up to $20 \mathrm{~cm} \mathrm{~s}^{-1}$ were negligible. At $25 \mathrm{~cm} \mathrm{~s}^{-1}$ there was a relatively large increase in fucoxanthin:chl $a_{\text {, }}$ together with the appearance of other accessory pigments. As in June, these pigments are not found in the upper $5 \mathrm{~mm}$ of sediment. 
Site 2
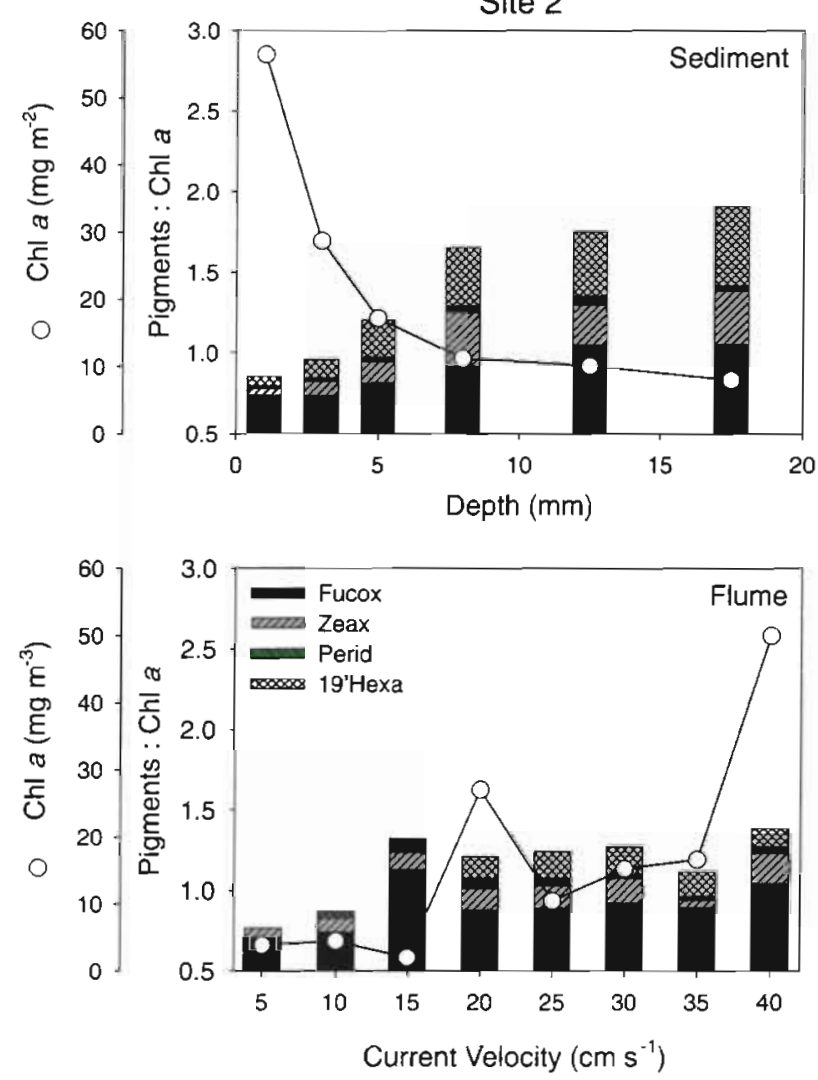

Site 4
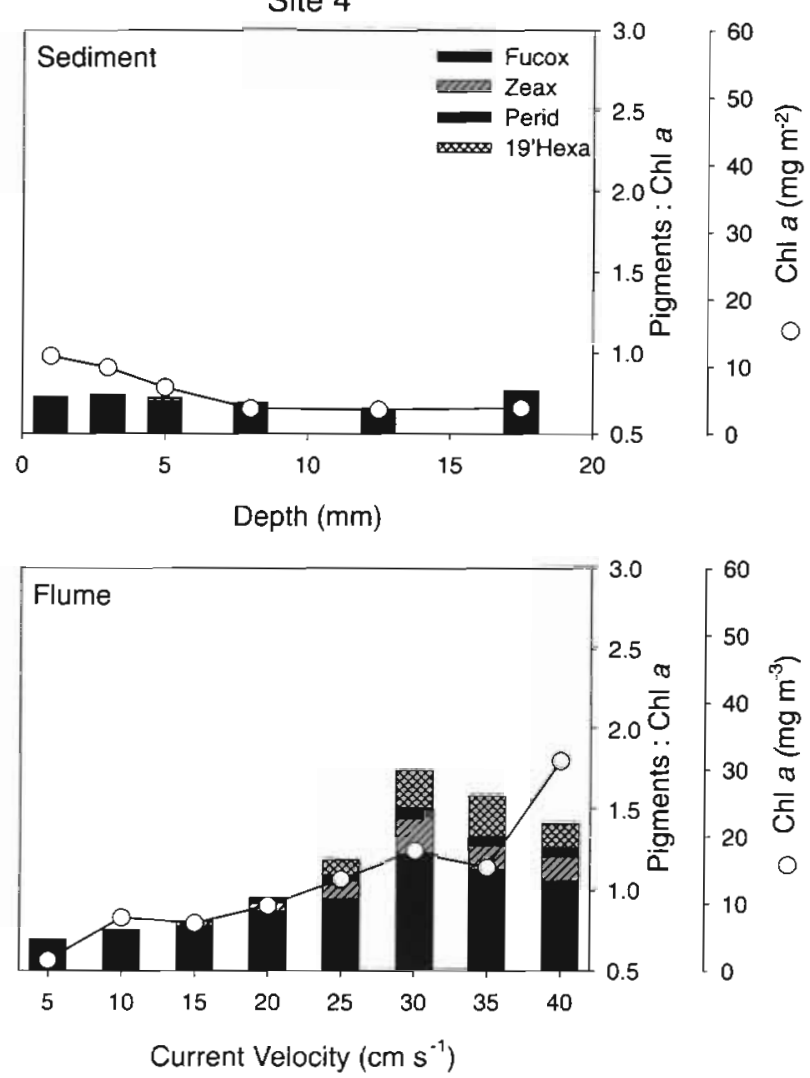

Fig. 4. Accessory pigment:chl a ratios of sediments and flume suspended material from Site 2 (silty) and Site 4 (sandy) in June 1997. (Fucox = diatoms; Zeax = cyanobacteria and/or detritus; Perid = dinoflagellates; $19^{\prime}$ hexa $=$ prymnesiophytes)

\section{Flume tidal simulation}

Cycles of sediment and microalgae resuspension and deposition were demonstrated in the tidal simulation experiment carried out using sediment from the sandy Site 4 (Fig. 6). Changes in SPM concentration reflected changes in current velocity, with a short time lag between the 2 cycles. Maximum current velocities during the 'flood' were $24 \mathrm{~cm} \mathrm{~s}^{-1}$ (but $31 \mathrm{~cm} \mathrm{~s}^{-1}$ in situ) with maximum SPM of $478 \mathrm{mg} \mathrm{m}{ }^{-3}$. Significant increases in SPM concentration beyond what was seen on the 'flood' only occurred during the 'ebb' at current velocities $\sim 30 \mathrm{~cm} \mathrm{~s}^{-1}$. Maximum current velocity during the 'ebb' was $40 \mathrm{~cm} \mathrm{~s}^{-1}$, and maximum SPM was $3067 \mathrm{mg} \mathrm{m}^{-3}$.

Chl a concentration at $T_{0}$ was high ( $>30 \mathrm{mg} \mathrm{m}^{-3}$ ). Diatoms (fucoxanthin) dominated the microalgae community, in particular Nitzschia closterium, with small amounts of 'green' algae (chl b) and cyanobacteria (zeaxanthin/lutein). Rapid deposition of chl a occurred at the start of the experiment when current velocities were $\sim 10 \mathrm{~cm} \mathrm{~s}^{-1}$. This was caused by settling of cells, and biodeposition due to suspension feeding by cockIes. The flume contained 8 cockles, equivalent to
47 ind. $\mathrm{m}^{-2}$, and their suspension-feeding activities were found to be significant at the lower current velocities ( $T_{0}$ and $T_{140}$ ). Overall, the temporal cycle of chl a was very similar to that of SPM, with increases and decreases occurring in response to changes in current velocity. Similarly, a major resuspension event occurred during the 'ebb' phase of the cycle when there was sediment erosion and bedload transport. In addition to a large increase in chl $a$, accessory pigment diversity and concentration increased, both in absolute terms and relative to $\mathrm{chl} a$. Following the peak in current velocity at $T_{210}$, both SPM and microalgae deposited extremely rapidly. It has been observed in other semi-quantitative deposition experiments that deposition of microalgae can be extremely rapid as SPM 'strips' the water clear of fine organic and inorganic material.

\section{In situ seston dỵamics}

Examples of the spatial and temporal changes in SPM, chl $a$, and \% chl $a$ (i.e., chl a/phaeopigments $\times$ $100 \%$ ) observed over part of a flood-ebb cycle at Sites 2 and 4 in June 1996, and at Site 2 in September 1996, 
are presented in Figs 7, 8, \& 9. Clear resuspension and deposition events on either side of the high water (HW) slack period can be seen. At both sites, there was a slight indication of chl a being resuspended slightly in advance of sediment. However, the relatively long time interval between samples (10 to $30 \mathrm{~min}$ ), combined with advective fluxes, make this observation less distinct than anticipated. Nevertheless, the influence of the underlying sediment type was evident when comparing Sites 2 (Fig. 7) and 4 (Fig. 8) in June.

At Site 4, changes in SPM occurred very rapidly as the larger sand grains were resuspended and then sank rapidly once the critical threshold for deposition was reached. Although chl a resuspension occurred slightly in advance of SPM, the deposition at slack water was less distinct as material is advected across the site. Similar concentrations and trends of SPM, chl $a$, and \% chl a were observed at Site 2, although resuspension of both SPM and chl a up into the water column was not as great because the underlying sediment is more stable. Advective fluxes make trends in $\% \mathrm{chl}$ a more difficult to distinguish. Nevertheless, at Site 2 in June, the relative amount of chl a was lowest during resuspension and highest during the slack period at $\mathrm{HW}+30 \mathrm{~min}$. At Site 4 in June, there was more of a vertical stratification, with highest \% chl a at the surface compared with immediately above the seabed.

In terms of seasonal changes at Site 2 (which displayed the greatest seasonality in sediment erodability and microalgal mat cover), temporal trends over the tidal cycle more closely resembled the sandy site (Site 4) in June. Material was being transported higher into the water column, and \% chl a distribution was more vertically stratified. Concentrations of suspended material in the water column also differed. SPM was greater in September than June (max. $399 \mathrm{mg} \mathrm{l}^{-1} \mathrm{com}$ pared with $289 \mathrm{mg} \mathrm{l}^{-1}$ ), while the absolute and relative amounts of chl a decreased significantly. Peak chl a was $19.5 \mathrm{mg} \mathrm{m}^{-3}$ in September compared with $89.1 \mathrm{mg}$ $\mathrm{m}^{-3}$ in June, while peak \% chl a was 500 in September compared with 1100 in June.

\section{DISCUSSION}

\section{Resuspension of chl a}

Overall, there was good agreement between the general conclusions of the flume and field experi-
Site 2
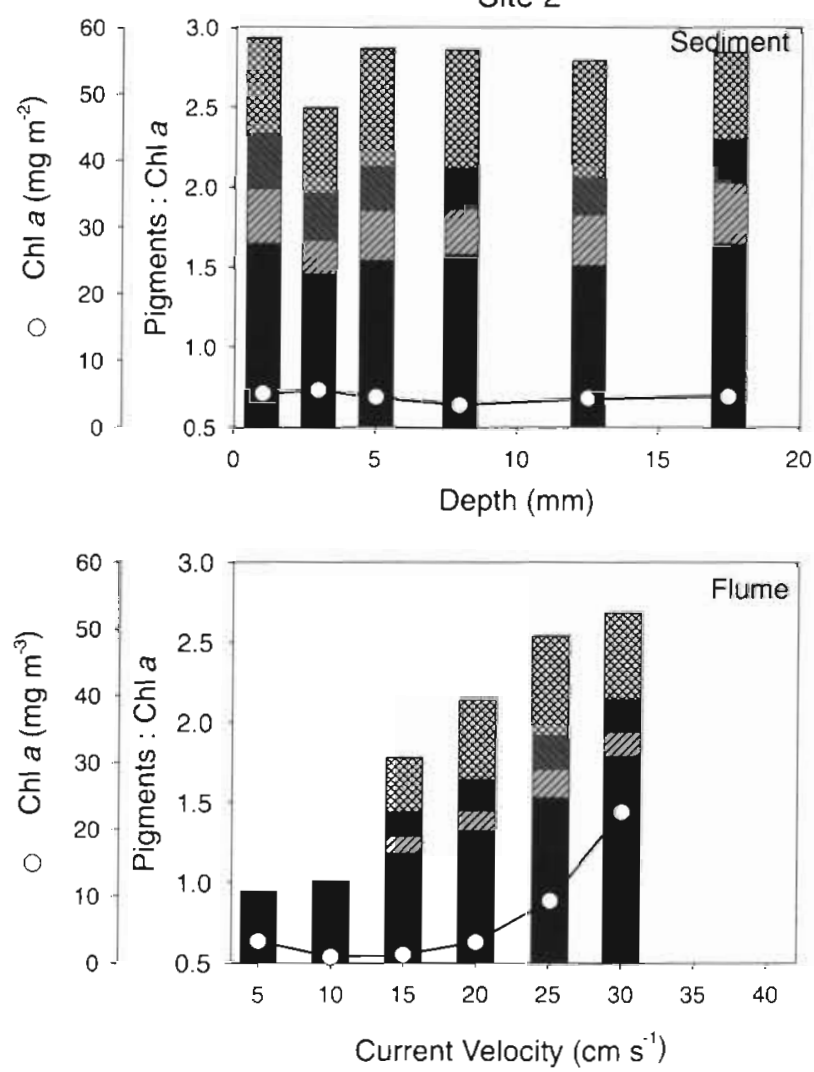

Site 4
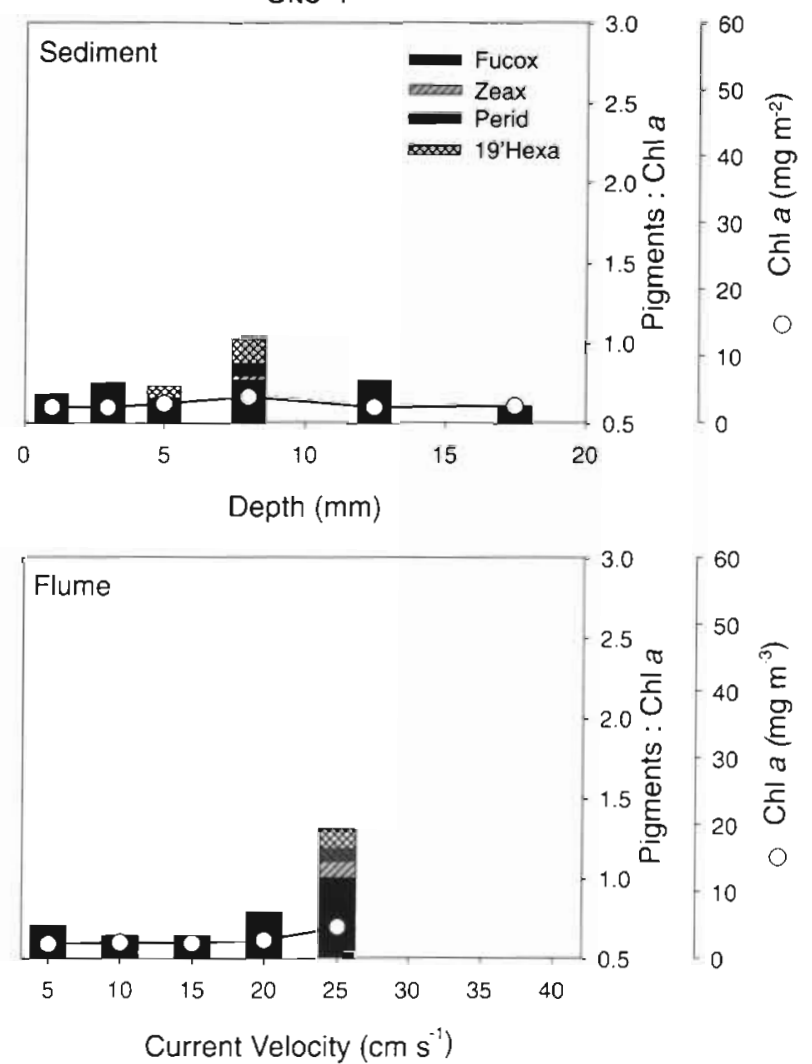

Fig. 5. Accessory pigment:chl a ratios of sediments and flume suspended material from Site 2 (silty) and Site 4 (sandy) in September 1997 (Fucox = diatoms; zeax = cyanobacteria and/or detritus; Perid = dinoflagellates; 19'hexa $=$ prymnesiophytes) 

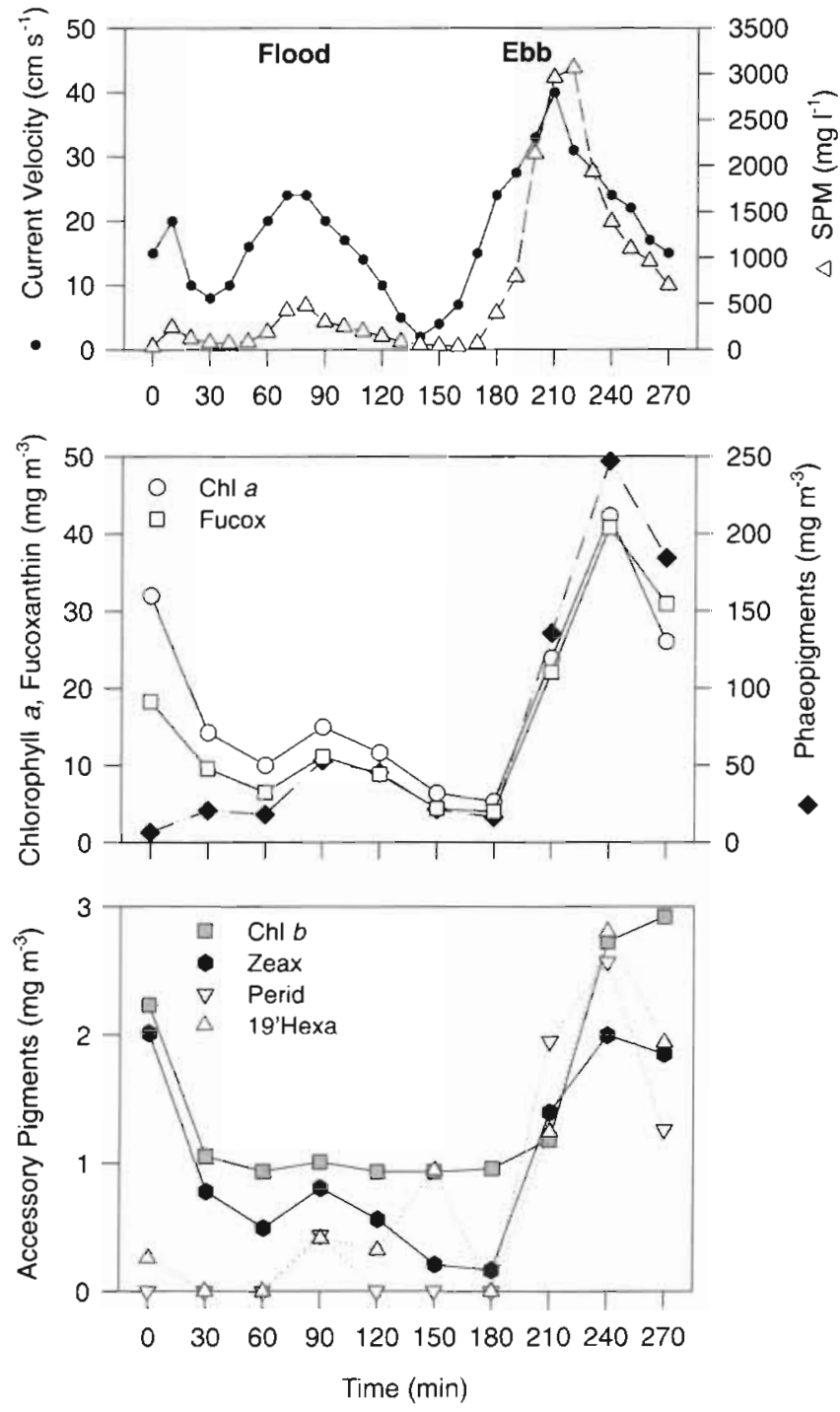

Fig. 6. Temporal changes in suspended particulate matter (SPM), chl $a$, phaeopigments and accessory pigment concentrations during a tidal simulation experiment in the annular flume, using sediment from Site 4 in June 1997. (Water depth $=21 \mathrm{~cm}$ )

ments. The flume experiments described in this paper demonstrated clear differences in both the amount and rate of microphytobenthos resuspended from the underlying substratum. Predicting spatial and temporal differences in mass of chl a resuspended is complex. It is mainly related to the erosion behaviour (threshold and rate) of the sediment, including the stabilising influence of the microbial mat (Paterson et al. 1990, Yallop et al. 1994), and the amount and vertical distribution of microphytobenthos available for resuspension. These factors are influenced by the physi$\mathrm{cal} / \mathrm{biochemical} \mathrm{properties} \mathrm{of} \mathrm{the} \mathrm{sediment,} \mathrm{as} \mathrm{well} \mathrm{as}$ the presence and feeding activities of benthic deposit and suspension feeders. The findings are in agreement with Grant \& Daborn (1994) and Blanchard et al. (1997).

On the Molenplaat, significant correlations between $U_{\text {crit, }}$ chl $a$ and colloidal carbohydrates have been reported (Widdows et al. 2000). Sandy sediments had low thresholds of erosion (sand grains roll at $15 \mathrm{~cm} \mathrm{~s}^{-1}$ ) with resuspension and bedload transport occurring at higher current velocities (Widdows et al. 2000). The low sediment stability, coupled with populations of bioturbators such as Arenicola marina (up to $17600 \mathrm{mg}$ AFDW m ${ }^{-2}$ ), results in low microphytobenthos biomass $\left(<11.5 \mathrm{mg}\right.$ chl a $\left.\mathrm{m}^{-2}\right)$ dominated by epipsammic and epipelic diatoms (Sabbe \& Vyverman 1991). The microphytobenthos is homogeneously distributed with depth and does not vary greatly on a seasonal basis (Lucas \& Holligan 1999). Resuspension of chl a from these sediments (e.g., Sites 4 and 5) was characterised by a gradual and continuous increase with increasing current velocity. Because epipsammic diatoms are attached to sand grains via EPS and cohesive clay coatings, the trends in chl a resuspension closely resembled those of the sediment.

Siltier sites are characterised by dense algal mats in the upper 1 to $2 \mathrm{~mm}$ composed of epipelic diatoms such as Navicula spp. and Nitzschia spp. Peak chl a biomass at the centrally located Site 2 was $56 \mathrm{mg} \mathrm{m}^{-2}$ in June. The dynamic relationship between benthic diatoms and silty sediments was rather different to that in sandy sediments, and was subject to greater seasonality and inter-annual variability, particularly at Site 3 . In 1996, the central silty region (Sites 2 and 3) was dominated by a dense microalgal mat which greatly enhanced sediment stability. Reduced sediment stability in 1997 (see Table 2) was probably the result of bioturbation caused by the more bivalve-dominated community. These temporal variations were reflected in chl a resuspension.

At Site 2 in June, when sediment stability was greatest during the benthic diatom bloom, chl a resuspension at low current velocities was negligible. At times there was a flux of chl a towards the sediment, which may have been caused by settling of Iarger diatom cells such as the pelagic form Coscinodiscus spp. and/or biodeposition by suspension feeders (Graf \& Rosenberg 1997. Thomsen \& Flach 1997) such as Cerastoderma edule and Mya arenaria. Net clearance and biodeposition rates were calculated at $5 \mathrm{~cm} \mathrm{~s}^{-1}$, with values greatest at Site $2\left(1701 \mathrm{~h}^{-1} \mathrm{~m}^{-2}\right.$ or $3.4 \mathrm{~g} \mathrm{~m}^{-2}$ $\mathrm{h}^{-1}$ at $20 \mathrm{mg} \mathrm{SPM} \mathrm{l}^{-1}$ in June 1996) (Widdows et al. 2000 ). At current velocities $>20$ to $25 \mathrm{~cm} \mathrm{~s}^{-1}$, the algal mat was stripped off in pieces, which introduced high concentrations of chl a into the water column and allowed the underlying sediment to erode rapidly. In September when there was no visible algal mat and 

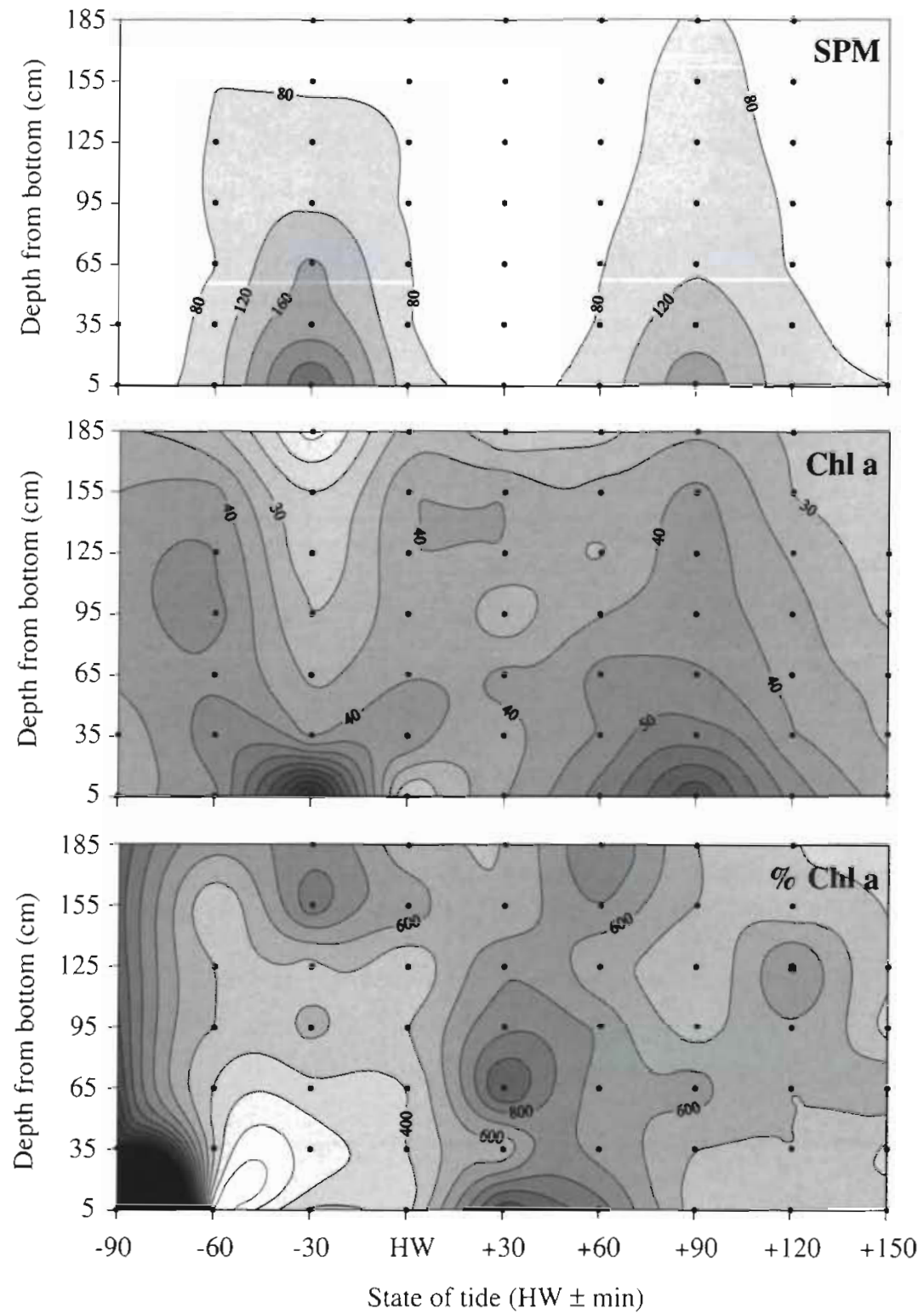

Fig. 7. Water column profiles of SPM $\left(\mathrm{mg} \mathrm{l}^{-1}\right)$, chl a $\left(\mathrm{mg} \mathrm{m}^{-3}\right)$, and \% chl a (of phaeopigments) over an immersion period, from a fixed point at Site 2 in June 1996. (HW = high water)

sediment stability was lower, resuspension kinetics of benthic diatoms and sediment were more closely coupled.

Site 1, situated on the edge of the tidal flat, has relatively high surface chl a (25 to $31 \mathrm{mg} \mathrm{m}^{-2}$ ) but low stability, as a result of populations of the bioturbator Macoma balthica and low colloidal carbohydrates (Widdows et al. 2000). The short emersion period at the site prevents desiccation and consolidation of the EPS, which is easily washed away during tidal inundation (Paterson et al. 1990). It was noted that during the initial stages of the flood tide, benthic diatoms were easily lifted off from the sediment surface at the tidal front, but were then deposited rapidly once the turbulent currents had broken the surface tension of the mucous biofilm.

\section{Ecological implications}

As a result of differences in sediment erodability (threshold and rate) and microphytobenthos biomass and distribution described previously, large differences in the quantity of microphytobenthos resuspended from the sediment in response to increasing current velocity were identified (see Table 3). Al- 

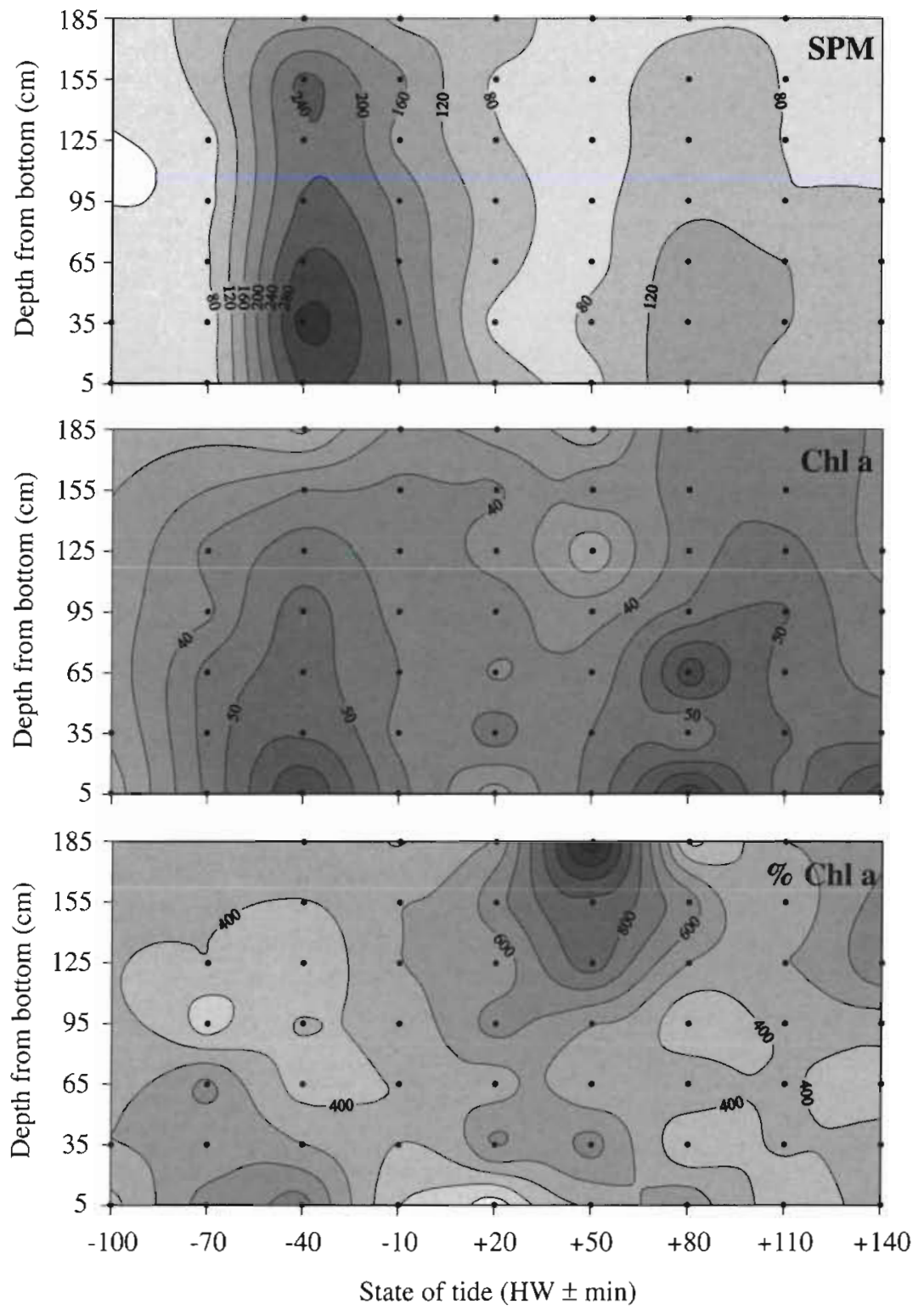

Fig. 8. Water column profiles of SPM ( $\mathrm{mg} \mathrm{l}^{-1}$ ), chl a $\left(\mathrm{mg} \mathrm{m}^{-3}\right)$, and \% chl a (of phaeopigments) over an immersion period, from a fixed point at Site 4 in June 1996

though siltier sediments contained 5 to $25 \times$ more chl $a$ in the surface layer than sandier sediments, less biomass was resuspended at current velocities approximately $<25 \mathrm{~cm} \mathrm{~s}^{-1}$. However, once the diatom biofilm had been stripped off, resuspension of chl a into the water column was rapid. These findings have important implications for the carbon supply to both the benthic and pelagic systems, and to sediment stability.

In general, sites with low thresholds of erosion lost a larger proportion of their sedimentary biomass during the resuspension process, sometimes in spite of relatively high surface chl a available (e.g., Site 1). These physically unstable sites situated at the edges of the flat were characterised by deposit-feeding macrofauna communities composed of Arenicola marina (Sites 1 and 4) and Macoma balthica (Site 1), although Hydrobia ulvae and Pygospio spp. were abundant in the centrally located Site 3. Deposit feeders themselves can reduce microphytobenthos abundance through grazing pressure, and bioturbation of the sediment, which makes it more erodable. Loss of benthic chl a has implications for benthic macro- and meio-faunal deposit feeders because they feed on microphytobenthos, as well as detritus (reviewed by Miller et al. 1996). Although microphytobenthos biomass may decline temporarily, in many cases in situ growth and advec- 

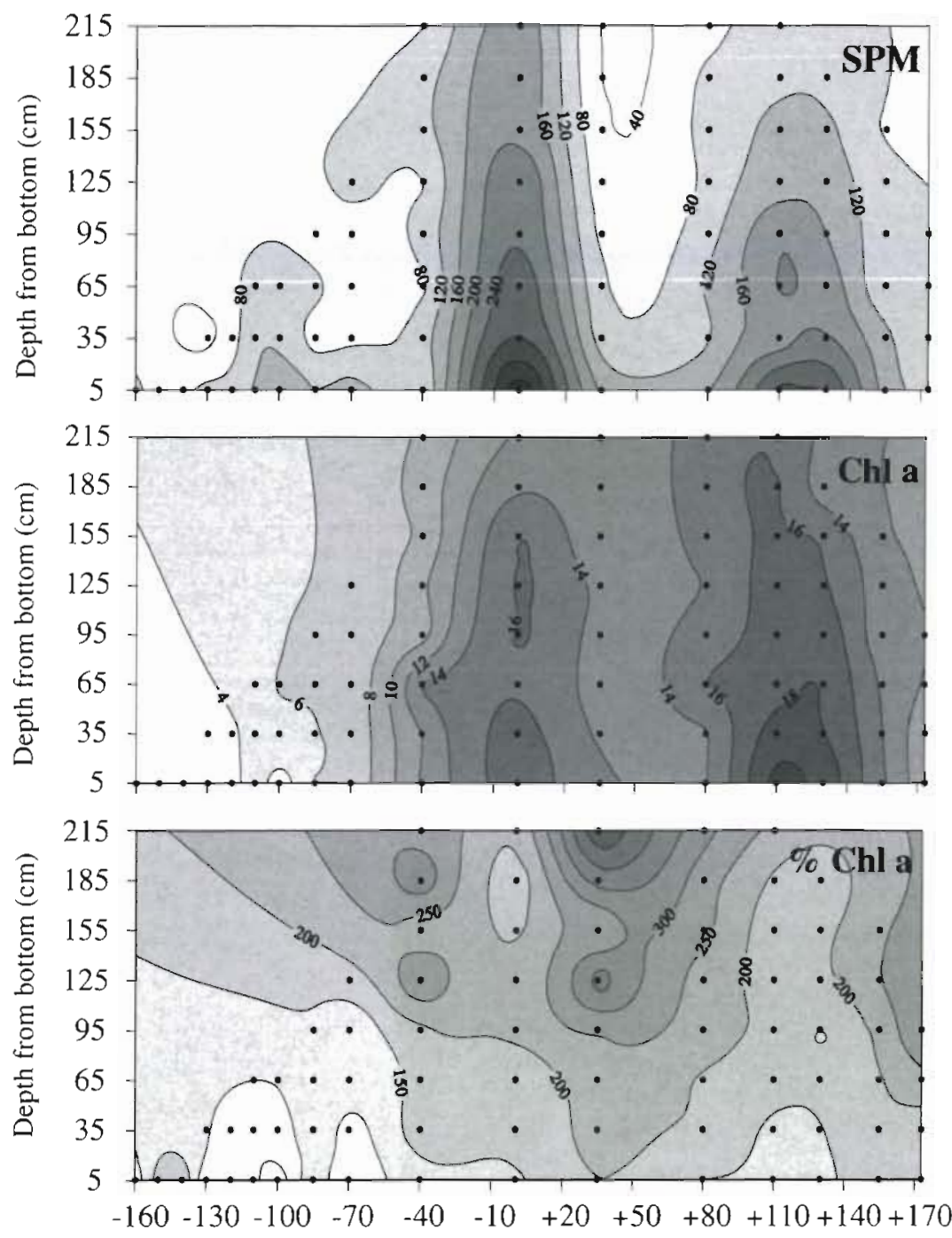

State of tide $(\mathrm{HW} \pm \mathrm{min})$

Fig. 9. Water column profiles of SPM ( $\left.\mathrm{mg} \mathrm{l}^{-1}\right), \mathrm{chl}$ a $\left(\mathrm{mg} \mathrm{m}^{-3}\right)$, and $\% \mathrm{chl}$ a (of phaeopigments) over an immersion period, from a fixed point at Site 2 in September 1996

tive transport have been found to be sufficient to resupply the population (Ray 1989). In the present study it was not possible to determine the relative contributions of advected or in situ resupply. However, primary productivity in June was high at Sites 1 (mean: $560 \mathrm{mg} \mathrm{O}_{2} \mathrm{~m}^{-2} \mathrm{~h}^{-1}$ ) and 4 (mean: $369 \mathrm{mg} \mathrm{O} \mathrm{m}^{-2} \mathrm{~h}^{-1}$ ) (Barranguet unpubl. data), which, together with redistribution of material during the rapid sedimentation and bedload transport observed in the field and flume, allowed microphytobenthos biomass to increase during the spring period.

The siltiest site (Site 2) in the central region of the Molenplaat had the lowest mean rate of primary pro- duction, $272 \mathrm{mg} \mathrm{O}_{2} \mathrm{~m}^{-2} \mathrm{~h}^{-1}$ (Barranguet unpubl. data), because of a narrow photic zone and nutrient limitation. It had high resistance to erosion and dense microalgal mats which sustained low losses of biomass whilst the biofilm remained intact. Once the biofilm had been compromised, the proportion of sedimentary biomass resuspended increased, and exposed the underlying sediment and phaeopigment-rich biomass to erosion. As a result the quality of microphytobenthos biomass resuspended (\% chl a) decreased with increasing current velocity. This was also observed in the sandier sediments. The siltier sites were characterised by suspension feeders which rely on advective trans- 
port of microalgae (phytoplankton enhanced by resuspended microphytobenthos) for food. Highest rates of suspension feeding and biodeposition were recorded at these sites (Widdows et al. 2000). When vertical mixing in the water column is reduced and benthic populations are dense, suspension feeders can temporarily deplete seston within the benthic boundary layer (Fréchette \& Bourget 1985, Cole et al. 1992, Muschenheim \& Newell 1992). Spatial and temporal variations in food quality, quantity and availability affect the population characteristics, distribution, individual growth and behaviour of suspension feeders (Fréchette \& Bourget 1985, Muschenheim \& Newell 1992). Because microalgae are concentrated at the sediment surface, they erode before the sediment and provide an organic-rich supply of food at moderate current velocities (20 to $30 \mathrm{~cm} \mathrm{~s}^{-1}$ ). At high current velocities when there is considerable resuspension of inorganic particles, growth of benthos may become inhibited.

The presence and importance of benthic microalgae as temporary members of the phytoplankton is a wellknown phenomenon. Contributions of up to $60 \%$ of total water column biomass have been reported (de Jonge \& van Beusekom 1992), and in shallow estuaries, much of the spatial variability in chl a concentration has been reported to be caused by resuspended microphytobenthos (Shaffer \& Sullivan 1988). Over short time scales, water column productivity in turbid estuaries may be dominated by resuspended microalgae, as the resident phytoplankton population are light limited (Shaffer \& Sullivan 1988, de Jonge \& van Beusekom 1992, de Jong \& de Jonge 1995). Benthic microalgae are photosynthetically competent, and can offset reduced system productivity during resuspension events that create increased turbidity (Macintyre \& Cullen 1996). The Westerschelde is a turbid estuary. Although the phytoplankton community is never nitrogen-limited, net pelagic photosynthetic production is relatively low due to the poor light penetration in the water column (Kromkamp et al. 1995). Therefore, over time scales of minutes to hours, resuspended benthic microalgae may make a considerable contribution to water column productivity. Coupled with the modelling study of Soetaert \& Herman (1995a), which predicts that overall benthic primary production in the Westerschelde estuary amounts to $60 \%$ of pelagic primary production, the potential importance of microphytobenthos in estuarine production flows is re-confirmed.

\section{Conclusions}

The combination of flume and field observations of microphytobenthos resuspension have identified that:
(1) Sediment erodability in terms of threshold of erosion and mass of sediment eroded, together with the biomass and distribution of microphytobenthos are important in determining the amount of chl a biomass resuspended at different current velocities. (2) Resuspension of microphytobenthos and sediment occurs simultaneously in sandier sediments. In silty sediments, the microbial mat resuspends before the underlying sediment. (3) The percentage of sedimentary biomass lost during resuspension is greater in more erodable sediments, and in the autumn compared with the spring, because of differences in the dynamic relationship between microphytobenthos and sediments. (4) Biomass is replaced by advection of rapidly depositing cells 'stripped' out of the water column by SPM, biodeposition by suspension feeders, and in situ primary production.

Acknowledgements. Much appreciation and thanks go to Jack Middelburg, Adri Sandee, Pieter van Rijswijk and Bernard Krebs for assistance with the in situ seston sampling in difficult conditions and SPM analysis. Colin Barrett developed the mini-rig apparatus at PML. This work is a contribution to the ELOISE Programme (ELOISE No. 116) in the framework of the ECOFLAT (Eco-Metabolism of a Tidal Flat) project carried out under contract ENV4-ct96-0216, jointly sponsored by the ENVIRONMENT and MAST programmes of the EU.

\section{LITERATURE CITED}

Barlow RG, Mantoura RFC, Gough MA, Fileman TW (1993) Pigment signatures of the phytoplankton composition in the northeastern Atlantic during the 1990 spring bloom. Deep-Sea Res II 40:459-477

Blanchard GF, Sauriau PG, Cariou-Le Gall V, Gouleau D, Garet MJ, Olivier F (1997) Kinetics of tidal resuspension of microbiota: testing the effects of sediment cohesiveness and bioturbation using flume experiments. Mar Ecol Prog Ser 151:17-25

Cahoon LB, Cooke JE (1992) Benthic microalgal production in Onslow Bay, North Carolina, USA. Mar Ecol Prog Ser 84: $185-196$

Cole BE, Thompson J, Cloern JE (1992) Measurement of filtration rates by infaunal bivalves in a recirculating flume. Mar Biol 113:219-225

Colijn F, de Jonge VN (1984) Primary production of microphytobenthos in the Ems-Dollard estuary. Mar Ecol Prog Ser 14:185-196

Davis WR (1993) The role of bioturbation in sediment resuspension and its interaction with physical shearing. J Exp Mar Biol Ecol 171:187-200

de Jong DJ, de Jonge VN (1995) Dynamics of microphytobenthos chlorophyll-a in the Scheldt estuary (SW Netherlands). Hydrobiologia 311:21-30

de Jonge VN, Colijn F (1994) Dynamics of microphytobenthos biomass in the Ems estuary measured as chlorophyll $a$ and carbon. Mar Ecol Prog Ser 104:185-196

de Jonge VN, van Beusekom JEE (1992) Contribution of resuspended microphytobenthos to total phytoplankton in 
the Ems estuary and its possible role for grazers. Neth J Sea Res 30:91-105

de Jonge VN, van Beusekom JEE (1995) Wind- and tideinduced resuspension of sediment and microphytobenthos in the Ems estuary. Limnol Oceanogr 40:766-778

Delgado M, de Jonge VN, Peletier H (1991) Experiments on resuspension of natural microphytobenthos populations Mar Biol 108:321-328

Demers S, Therriault JC, Bourget E, Bah A (1987) Resuspension in the shallow sublittoral zone of a macrotidal estuarine environment: wind influence. Limnol Oceanogr 32: $327-339$

Fréchette M, Bourget E (1985) Food limited growth of Mytilus edulis $\mathrm{L}$. in relation to the benthic boundary layer. Can $J$ Fish Aquat Sci 42:1158-1165

Graf G, Rosenberg R (1997) Bioresuspension and biodeposition: a review. J Mar Syst 11:269-278

Grant J, Daborn G (1994) The effects of bioturbation on sediment transport on an intertidal mudflat. Neth J Sea Res 32 $63-72$

Heip C (1988) Biota and abiotic environment in the Wester schelde estuary. Hydrobiol Bull 22:31-34

Jumars PA, Nowell ARM (1984) Effects of benthos on sediment transport: difficulties with functional grouping. Cont Shelf Res 3:115-130

Kromkamp J, Peene J, van Rijswijk P, Sandee A, Goosen $N$ (1995) Nutrients, light and primary production by phytoplankton and microphytobenthos in the eutrophic, turbid Westerschelde estuary (The Netherlands). Hydrobiologia 311(Dev Hydrobiol 110):9-19

Lorenzen CJ (1967) Determination of chlorophyll and phaeopigments: spectrophotometric equations. Limnol Oceanogr $12: 343-346$

Lucas CH, Holligan PM (1999) Nature and ecological implications of algal pigment diversity on the Molenplaat tidal flat (Westerschelde estuary). Mar Ecol Prog Ser 180:51-64

MacIntyre HL, Cullen JJ (1996) Primary production by suspended and benthic microalgae in a turbid estuary: timescales of variability in San Antonio Bay, Texas. Mar Ecol Prog Ser 145:245-268

Mantoura RFC, Llewellyn CA (1983) The rapid determination of algal chlorophyll and carotenoid pigments and their breakdown products in natural waters by reverse-phase high-performance liquid chromatography. Analyt Chim Acta 151:297-313

Mehta AJ (1988) Laboratory studies on cohesive sediment deposition and erosion. In: Dronkers J, van Leussen V (eds) Physical processes in estuaries. Springer-Verlag Berlin, p 427-445

Miller DC, Geider RJ, MacIntyre HL (1996) Microphytobenthos: the ecological role of the 'secret garden' of unvegetated, shallow-water marine habitats. II. Role in sediment stability and shallow-water food webs. Estuaries 19 $202-212$

Editorial responsibility: Otto Kinne (Editor),

Oldendorf/Luhe, Germany
Muschenheim DK, Newell CR (1992) Utilization of seston flux over a mussel bed. Mar Ecol Prog Ser 85:131-136

NIOO (Netherlands Institute of Ecology) (1996) Progress Report. Middelburg J, Mooij W, van der Putten W (eds) Ponsen \& Looijen bv, Wageningen

Paterson DM, Crawford RM, Little C (1990) Subaerial exposure and changes in the stability of intertidal estuarine sediments. Estuar Coast Shelf Sci 30:541-556

Ray A.J (1989) Influence of sediment dynamics and deposit feeding on benthic microalgae. MS thesis, University of Delaware, Lewes, DE

Roegner GC (1998) Hydrodynamic control of the supply of suspended chlorophyll a to infaunal estuarine bivalves. Estuar Coast Shelf Sci 47:369-384

Sabbe K, Vyverman W (1991) Distribution of benthic diatom assemblages in the Westerschelde estuary (Zeeland, The Netherlands). Belg J Bot 124:91-101

Shaffer GP, Sullivan MJ (1988) Water column productivity attributable to displaced benthic diatoms in well-mixed shallow estuaries. J Phycol 24:132-140

Soetaert K, Herman PMJ (1995a) Carbon flows in the Westerschelde estuary (The Netherlands) evaluated by means of an ecosystem model (MOSES). Hydrobiologia 311: $247-266$

Soetaert K, Herman PMJ (1995b) Estimating estuarine residence times in the Westerschelde estuary (The Netherlands) using a box model with fixed dispersion coefficients. Hydrobiologia 311:215-224

Sundbäck K, Graneli W (1988) Influence of microphytobenthos on the nutrient flux between sediment and water: a laboratory study. Mar Ecol Prog Ser 43:63-69

Thomsen L, Flach E (1997) Mesocosm observations of fluxes of particulate matter within the benthic boundary layer. J Sea Res 37:67-79

Widdows J, Brinsley MD, Elliott M (1998a) Use of in situ flume to quantify particle flux (deposition rates and sediment erosion) for an intertidal mudflat in relation to changes in current velocity and benthic macrofauna. In: Black KS, Paterson DM, Cramp A (eds) Sedimentary processes in the intertidal zone, Vol 139. Special Publications, Geological Society, London, p 85-97

Widdows J, Brinsley MD, Bowley N, Barrett C (1998b) A benthic annular flume for in situ measurement of suspension feeding/biodeposition rates and erosion potential of intertidal cohesive sediments. Estuar Coast Shelf Sci 46:2-38

Widdows J, Brinsley MD, Salkeld PN, Lucas CH (2000) Influence of biota on spatial and temporal variation in sediment erodability and material flux on a tidal flat (Westerschelde, The Netherlands). Mar Ecol Prog Ser 194:23-37

Yallop ML, de Winder B, Paterson DM, Stal LJ (1994) Comparative structure, primary production, and biogenic stabilization of cohesive and non-cohesive marine sediments inhabited by microphytobenthos. Estuar Coast Shelf Sci $39.565-582$

Submitted: August 16, 1999; Accepted: October 18, 1999

Proofs received from author(s): March 29, 2000 